\title{
A Cognitive Capabilities and Gender Differences in Transition Period: A Study Of Lucknow City
}

\author{
Singh Nivedita* and Singh Neetu** \\ *M.sc.Scholar, Dept. of HD\&FS, School for Home Science \\ **Assistant Professor Dept. of HD\&FS, School for Home Science \\ Babasaheb Bhimrao Ambedkar University (A Central University),Vidya Bihar, Raibareli Road, Lucknow, \\ INDIA
}

\begin{abstract}
The potential effect of gender on intellectual abilities remain controversial. A variety of research has been conducted on A Cognitive Capabilities and Gender Differences in transition period Objective: To assess the cognitive capabilities of male and female in transition period.. This study was conducted on 120 adolescence (10-13 years) government and private school in Lucknow city. The duration of the study was 11 months (July2012 - May 2013). The approaches adopted for the study was multi stage random sampling. The tools in the present study were predesigned and pretested Questionnaire for family level information and cognitive capabilities test during transition period develop by P.Vasundhara also used to assess of cognitive development. In this area there are found no significant difference male and female in class inclusion and combinatorial thinking. Out of five Schemes only two have a highly significant relationship viz; Time and motion and Co-ordinate system. Highly significant differences were found between male and female with corresponding value of formulating hypotheses and co-ordinate system. Majority of male and female belonging to transition period, minimum in late concrete formal operational stage.
\end{abstract}

KEYWORDS: Cognitive development, Male, Female, Cognitive Capabilities, Transition period.

\section{INTRODUCTION:}

Cognitive refers to the inner processes and products of the mind that lead to "knowing ". It includes all mental activity - attending remembering, symbolizing, categorizing, planning, reasoning problem solving creating and fantasizing. According to Piaget around age 11 young people enter the formal operational stage, in which they develop the capacity for abstract scientific thinking. Whereas concrete operational children can operate on reality. Formal operational adolescents can "operate on operations "(innelder Piaget 1955/1958). The cognitive development age 6 to 14 years" The years between 6 and 14-middle childhood and early adolescence — are a time of important developmental advances that establish children's sense of identity.

During these years, children make strides toward adulthood by becoming competent, independent, self-aware, and involved in the world beyond their families. Biological and cognitive changes transform children's bodies and minds. That the man and women have differences cognitive profile is becoming less and less debated: even if some people still argue that the alleged differences between male and female cognitive aptitudes is nothing mare than a culture stereotype, accumulating scientific evidence makes a compelling case for an innate disparity between a man and women is brain.

Objective: To assess the cognitive capabilities of male and female in transition period..

Material and Methods: The study was conducted in the year 2012-13. The sample size was 120 adolescence of government and private school between the ages ranges of 10-13 years Lucknow City U.P. The study was carried out in the area of Banglabazar, Ruchikhand and Ambedkar Nagar from $5^{\text {th }}$ Zone. Multi stage random sampling used for select the sample size. Predesigned and pretested Questionnaire for used as a tools family level and individual information and Cognitive Capabilities Test for transition period: CCT-T) developed by (P.Vasundhara) was used for assessing the Cognitive Capabilities. Techniques: family level variable such as religion cost type of family, family size household structure, income per-capita income household amenities and socio-economic status. Individual information covers the variable age. Literacy status, type of school, extra curriculum, Exposure of media. Cognitive Capability test consists of 3 parts. Each part divided into 10 questions, 12 questions and 03 questions, respectively. The maximum score is 125 and every part had repeat scoring of marks i.e. 63,44 and 18, correspondly. The scoring is calculated on the following criteria. 


\begin{tabular}{|c|c|c|c|c|c|c|c|}
\hline \multirow[t]{4}{*}{ A)- } & Discriminatory Index range & \multicolumn{6}{|c|}{0.10 to 0.66} \\
\hline & Difficulty Value range & \multicolumn{6}{|c|}{$14 \%$ to $65 \%$} \\
\hline & & \multicolumn{3}{|c|}{$6^{\text {th }}$ std. } & \multicolumn{3}{|c|}{$7^{\text {th }}$ std. } \\
\hline & & Total & Male & Female & Total & Male & Female \\
\hline \multirow[t]{2}{*}{ B)- } & Mean & 51.34 & 49.68 & 53.05 & 55 & 56 & 55 \\
\hline & Std. & 19.09 & 19.35 & 18.54 & 19 & 18 & 19 \\
\hline C)- & Qualitative score & \multicolumn{6}{|c|}{$\begin{array}{l}\text { 2B late concrete period), 2B/3A (transition period), 3A (early formal operational } \\
\text { stage). }\end{array}$} \\
\hline D)- & Quantitative score & \multicolumn{6}{|c|}{$63+44+18=125$} \\
\hline
\end{tabular}

\section{RESULTS AND DISCUSSION:}

_Assessment of Cognitive capabilities according to gender:-

(Part I) Combinatorial thinking- Class inclusion

\begin{tabular}{|c|c|c|c|c|c|c|c|}
\hline \multicolumn{8}{|c|}{ Across Gender } \\
\hline S.No & \multirow[t]{2}{*}{ Schemes of Thought } & \multicolumn{2}{|c|}{$\begin{array}{c}\text { Male } \\
\mathrm{N}=60\end{array}$} & \multicolumn{2}{|c|}{$\begin{array}{c}\text { Female } \\
N=60\end{array}$} & \multirow[t]{2}{*}{$\mathrm{t}$ - value } & \multirow[t]{2}{*}{ P value } \\
\hline & & Mean & S.d. & Mean & S.d. & & \\
\hline 1- & Combinatorial Thinking & 16.73 & 6.959 & 21.54 & 6.867 & 0.49 & .825 \\
\hline 2- & Class Inclusion & 5.89 & 4.031 & 6.62 & 2.996 & 5.998 & .016 \\
\hline
\end{tabular}

The above table analyzed that cognitive capability in transition period according to across gender. The table also shows that male mean value $16.73 \pm 6.959$ and female mean value $21.54 \pm 6.867$ in combinatorial thinking, $5.89 \pm 4.031$ of male and $6.62 \pm 2.996$ of female in class inclusion.

There is no significant difference male and female in class inclusion and combinatorial thinking.

(Part -2) Proportionality- Co-ordinate system

\begin{tabular}{|c|c|c|c|c|c|c|c|}
\hline \multirow{3}{*}{ S.No. } & \multicolumn{7}{|c|}{ Across gender } \\
\hline & \multirow[t]{2}{*}{ Schemes of Thought } & \multicolumn{2}{|c|}{$\begin{array}{l}\text { Male } \\
\mathrm{N}=60\end{array}$} & \multicolumn{2}{|c|}{$\begin{array}{c}\text { Female } \\
\mathbf{N}=60\end{array}$} & \multirow[t]{2}{*}{ t value } & \multirow[t]{2}{*}{ P value } \\
\hline & & Mean & S.d. & Mean & S.d. & & \\
\hline 1- & Proportionality & 10.81 & 5.483 & 13.10 & 5.168 & .252 & .617 \\
\hline $2-$ & Time and Motion & 1.89 & 1.174 & 2.04 & 1.590 & 8.565 & $.004 * *$ \\
\hline 3- & Conservation of area & 3.89 & 2.867 & 4.20 & 2.777 & 1.228 & .270 \\
\hline 4- & Geometrical Section & 1.60 & 1.109 & 1.84 & 1.390 & 1.224 & .271 \\
\hline $5-$ & Co-ordinate System & 3.87 & 2.637 & 4.96 & 3.188 & 9.569 & $.002 * *$ \\
\hline
\end{tabular}

Mean value of male $10.81 \pm 5.483$ and female $13.10 \pm 5.168$ in proportionality, $1.89 \pm 1.174$ male time and motion,

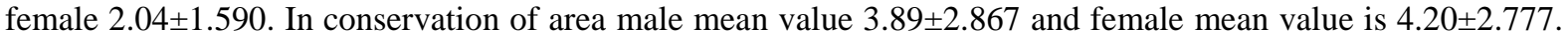
Were $1.60 \pm 1.60$ male mean value and female mean value $1.84 \pm 1.390$ in geometrical section. Mean value of male in co-ordinate system is $3.87 \pm 2.637$ and female $4.96 \pm 3.188$.

As per co-ordinate system, there are five division for their assessment and out of which only two have a highly significant relationship viz; Time and motion and Co-ordinate system.

(Part-3) Conservation of weight - Testing hypotheses

\begin{tabular}{|c|c|c|c|c|c|c|c|}
\hline \multirow{3}{*}{ S.No. } & \multicolumn{7}{|c|}{ Across gender } \\
\hline & \multirow[t]{2}{*}{ Schemes of Though } & \multicolumn{2}{|l|}{$\begin{array}{l}\text { Male } \\
\mathrm{N}=60\end{array}$} & \multicolumn{2}{|c|}{$\begin{array}{c}\begin{array}{c}\text { Female } \\
\mathbf{N}=60\end{array}\end{array}$} & \multirow[t]{2}{*}{ t-Value } & \multirow[t]{2}{*}{ P value } \\
\hline & & Mean & S.d. & Mean & S.d. & & \\
\hline 1- & Conservation of weight & 1.93 & 1.448 & 2.18 & 1.335 & 4.520 & .036 \\
\hline $2-$ & Conservation of volume & 2.18 & 1.335 & 1.88 & 1.913 & 1.681 & .197 \\
\hline 3- & Formulating Hypotheses & 1.88 & 1.913 & 2.34 & 1.319 & 8.437 & $.004 * *$ \\
\hline $4-$ & Testing Hypotheses & 2.34 & 1.319 & 1.98 & 1.436 & 7.633 & $.007 * *$ \\
\hline
\end{tabular}


This table reveals that $1.93 \pm 1.448$ male and $2.18 \pm 1.335$ female in conservation of weight were in conservation of volume male mean value is $2.18 \pm 1.335$, female mean value is $1.88 \pm 1.913$. Mean value of male in formulating hypotheses $1.88 \pm 1.913$, female value $2.34 \pm 1.319$. And in testing hypotheses $2.34 \pm 1.319$ is mean value of male and $1.98 \pm 1.436$ of female.Highly significant differences were found between male and female with corresponding value of formulating hypotheses and co-ordinate system.Ratul Bora also given the cognitive level of girls of Mishing community in Lakhimpur and Dhemaji is better than the boys (2012). Strand was given same study the mean value reasoning score for girls was 2.2 standard score point higher than boys (2006).

Cognitive analysis suggesting significant gender differences in certain areas of self-perceived performance, with females demonstrating significantly higher levels of self-regulation and a more positive attitude to academic study than their male counterparts.( Chan Wah S and Downing K. 2008) .(Pinker \& Spelke 2005): Points out that although men and women do not differ in intelligence men tend to have statistically better throwing mental rotation and mathematical problem-solving abilities whereas women and more dexterous and have a better visual memory and better mathematical calculation skills.

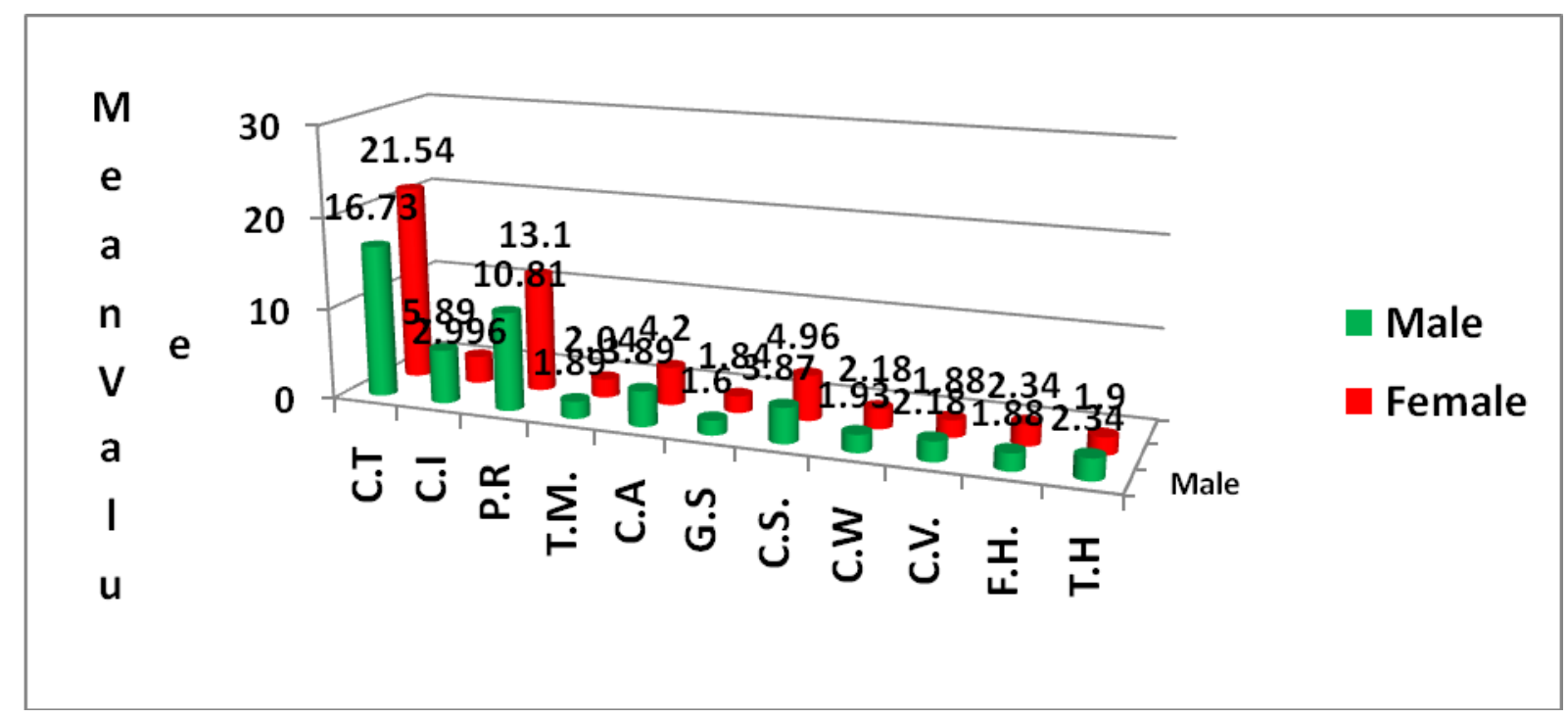

\section{CONCLUSION:}

In the current study, we used a Cognitive Capabilities scale to measure Cognitive Development that was founded differences in gender. Result demonstrated No significant difference male and female in class inclusion and combinatorial thinking. Out of five Schemes only two have a highly significant relationship viz; Time and motion and Co-ordinate system. Highly significant differences were found between male and female with corresponding value of formulating hypotheses and co-ordinate system. The adolescents have different interests, the teachers should try to find out their interests and utilize them in teaching learning situations. Independent learning for such adolescents is also a welcome process.

\section{REFERENCES}

[1] Bora R. 'level of cognitive development and personality pattern of Mishing adolescents in Assam; International referred Research journal, (3), 2012; 69-71.

[2] B.Y-Lean "Developmental mechanisms leading to cognitive disparities between men and women",2005;1-17.

[3] Coon H et. al. "Community influence on cognitive ability" Journal of intelligence, (16), 1992; 169-188.

[4] Piaget's theory of cognitive development (Accessed at http://en.wikipedia.org/wiki/Piaget\%27s theory of cognitive developmen on dated 19/11/2012.)

[5] Adolescence: cognitive transitions chapter 2 (Accessed at hill.com/sites/0072820144/student_view0/chapter9/ on dated 24/11/2012)

[6] Laura E.Berk: child development "Cognitive Development Piagetian, core Knowledge, and Vygotskian Perspectives", $7^{\text {nd }}$ ed. published by prentice -hall of India Private Limited New Delhi, 2007; 219-251.

[7] Vasundhara P. 'Cognitive capabilities test for transition period', 2005.

[8] Valanides N. 'Formal Reasoning Abilities and School Achievement; Studies in Educational Evaluation, (23), 1997; 169-185. 